\title{
CHANGES IN CONCENTRATIONS OF ORGANIC MATTER IN THE MOUTHS OF THE DOTNUVELE AND SMILGA RIVERS
}

Stefanija MISEVIČIENĖ, Water Resources Engineering Institute, Aleksandras Stulginskis University, Universiteto 10, LT-53361 Akademija, Kaunas distr., Lithuania; stefanija.miseviciene@ asu.lt

\begin{abstract}
The quality of water in rivers of central Lithuania is often bad due to intensive anthropogenic activities. When rivers flow through the town's territory, concentrated pollution, such as rainwater, industrial and productional waste water discharges, contributes to diffuse sources of pollution. If biogenic substances are the main indicators for diffuse pollution, organic matter, expressed as BOD, is the indicator for concentrated pollution. The article provides the 2013 - 2017 monitoring data on the changes of organic matter in the water of the Dotnuvele and Smilga Rivers and discusses the reasons for fluctuations in concentrations of BOD7. The aim of the research is to investigate the changes in the organic matter of the Dotnuvele and Smilga Rivers, depending on meteorological factors.

For chemical analysis, water samples were taken quarterly. Water analysis was carried out by the ASU Chemical Analytical Laboratory of Water Resources Engineering Institute. The amount of organic matter $\left(\mathrm{BOD}_{7}\right)$ is calculated as the difference in oxygen content after 7 days of incubation, while the amount of dissolved oxygen $\left(\mathrm{O}_{2}\right)$ in the water is determined by the electrochemical probe method. The concentrations of $\mathrm{BOD}_{7}$ and $\mathrm{O}_{2}$ in the water of both rivers is compared with the criteria for assessing the ecological status of surface water bodies.

The research has shown that the dissolved oxygen concentrations in rivers' water are strongly influenced by water temperature and precipitation. The lower the temperature, the more of the dissolved oxygen is found in rivers' water $(r=-0.64)$. A lower precipitation amount, which reaches the rivers, increases the amount of dissolved oxygen in them $(r=-0.45)$. The increase of $\mathrm{BOD}_{7} \mathrm{concentrations}$ in rivers' water was caused by higher precipitation amount $(\mathrm{r}=0.46)$, higher air $(\mathrm{r}=0.41)$ and lower water temperature $(\mathrm{r}=-0.41)$. The ecological status of the Dotnuvele River was usually good, while Smilga was average.
\end{abstract}

Keywords: biochemical oxygen demand, dissolved oxygen, concentration, ecological state, surface water

\section{INTRODUCTION}

The ecological status of rivers' water usually degrades due to the diffuse pollution, caused by intensive agriculture, due to the concentrated pollution, which is the pollution from urban rain and industrial as well as productional waste water discharges, due to international pollution, which includes the pollution load coming from neighbouring countries, as well as the historical pollution caused by a long-term past pollution. Recently, a decreasing trend in rivers' water pollution has been observed. According to the monitoring data of surface water bodies, which is carried out in Lithuania according to the National Environmental Monitoring Program 2011-2017, it was determined that 49\% of Lithuanian rivers meet good or very good ecological status. In the eastern, south-eastern and western regions of Lithuania, where human activity is less intense, 53-65\% of all water bodies have met a very good and good ecological status. Major problems in surface water bodies have been identified in intensive agricultural areas, i.e. northern, central and southwestern Lithuania, where 50-79\% of water bodies do not meet the requirements of good ecological status (Environmental..., 2016).

Pollution with organic substances in surface water is indicated by biochemical oxygen consumption. It reduces the amount of oxygen in water, deteriorates water quality, causes unwanted growth of algae, water weeds and sludge, as well as changes in water colour. Organic substances flow into rivers from farming fields that are in the river basins, from industrial and domestic waste water treatment plants and rainwater dischargers. If the rivers are highly eutrophied, a significant amount of organic matter is formed in the rivers themselves due to the degradation of plants and the vital activity of microorganisms (Nikanorov, 1989).

The Nevezis is a polluted River, because $74 \%$ of surface water bodies in its sub-basin do not meet good ecological status (Environmental..., 2016). The pollution of the Nevezis River is greatly influenced by its tributaries, which flow through the fertile soils of the Middle Lithuanian Lowland, collect nutrients and degrade water quality. The largest of the four tributaries of the Nevezis River in Kedainiai town are the Smilga and Dotuvele Rivers. The sources of concentrated pollution in their basins are municipal wastewater treatment plants, rain-treatment equipment and Kedainiai canning factory. Not all inhabited houses are connected to the central sewage system, and part of surface water flows from the city directly to the river. Sewage comes into Dotnuvele and Smilga from various settlements that are in the rivers' basins.

Copyright (C) 2017 The Authors. Published by Aleksandras Stulginskis University. This is an open-access article distributed under the terms of the Creative Commons Attribution License (CC-BY 4.0), which permits unrestricted use, distribution, and reproduction in any medium, provided the original author and source are credited. 
Environmental organisation of these rivers was completed in 2009-2012: rivers' water and banks were cleaned of harmful substances. After that, an annual maintenance of cleaned water bodies and rivers' water monitoring was carried out for five years.

The assessment of the status of surface water bodies is regulated by "The Methodology for Determining the State of Surface Water Bodies", approved by the Minister of Environment of the Republic of Lithuania on the $4^{\text {th }}$ August 2016 , order No. D1-533. The status of surface water bodies is assessed by analysing the data from the research site or sites that represent the status of the water body or according to the results of the Water Quality Modeling (Surface..., 2016).

The concentrations of biochemical oxygen demand (BOD) in water increase when water is polluted with organic matter (Simon et al., 2011). Since oxygen is required for the organic matter to oxidise, the higher the concentration of BOD in water, the less oxygen is left. This has a very negative effect on aquatic organisms that split organic matter into inorganic (Mwinyihija, 2010).

The aim of the research is to investigate the changes in organic matter content of the Dotnuvele and Smilga Rivers, depending on meteorological factors.

\section{THE PLACE AND METHODS OF RESEARCH}

The Dotnuvele and Smilga Rivers, flowing through Kedainiai town, are the right tributaries of the Nevezis River, flowing in at 59 and $58 \mathrm{~km}$ from the mouth (Fig. 1).

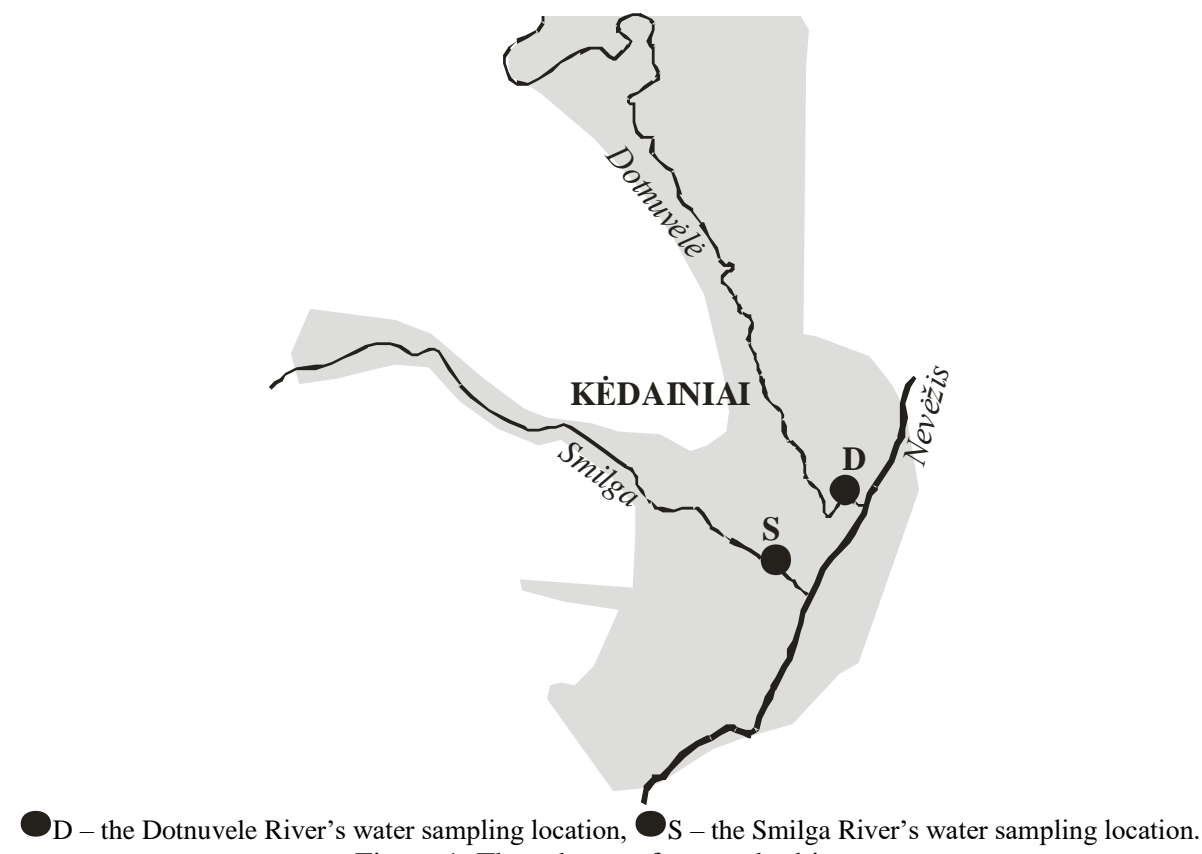

Figure 1. The scheme of research object.

Even though the Smilga River is almost twice shorter $(32 \mathrm{~km})$ than Dotnuvele $(60.9 \mathrm{~km})$, its basin is almost the same $\left(208.8 \mathrm{~km}^{2}\right)$ compared to Dotnuvele's $\left(192.7 \mathrm{~km}^{2}\right)$. The flow velocity of Dotnuvele current is $0.2-0.9 \mathrm{~m} \mathrm{~s}^{-1}$, it is dammed in 4 places. The flow velocity of Smilga current is $1.08 \mathrm{~m} \mathrm{~s}^{-1}$, and its valley is adjusted in the downriver. The cleaning of $1.95 \mathrm{~km}$ length of the Dotnuvele River (measured from the mouths of the river) as well as restoration of $10 \mathrm{~m}$ width of coastal strip was completed in 2012. In 2013, $1.98 \mathrm{~km}$ length of the Smilga River and 2 ha of coastal land was cleaned, and $5157 \mathrm{~m}^{3}$ of sludge removed. Water samples were taken from the mouths of the Dotnuvele (D) and Smilga (S) Rivers four times a year - in March, May, August, and November. Chemical analysis, was done by Chemical Analytical Laboratory of Water Resources Engineering Institute of Aleksandras Stulginskis University according to methods specified in the literature (Unified..., 1994). BOD $_{7}$ was determined by estimating the difference in oxygen level after seven days of incubation. Dissolved $\mathrm{O}_{2}$ amount in water was determined using the electrochemical probe method.

Surface water bodies' quality currently is assessed according to "The Surface Water Bodies' State Evaluation Methodology" approved by the Minister of Environment of the Republic of Lithuania. According to this methodology, the ecological state of rivers is divided into 5 classes from a very good state, when $\mathrm{BOD}_{7}<2.3$, dissolved oxygen $>8.5$ to a very bad state, when $\mathrm{BOD}_{7}>7 \mathrm{mg} \mathrm{O}_{2} \mathrm{l}^{-1}$, dissolved oxygen $<3.0 \mathrm{mg} \mathrm{l}^{-1}$ (Surface..., 2016).

Mathematical and statistical analysis of the data was performed using the computer program MS Excel 2010 and Statistica v.5.

\section{RESULTS AND DISCUSSION}

An increase in organic matter concentrations in rivers' water means that the rivers are polluted (Simon et al., 2011; Chen et al., 2012; Gustavsson, Engwall, 2012, Wen et al., 2017). The concentration of organic matter in rivers' water can be judged from biochemical oxygen demand. BOD is the dissolved amount of oxygen in water that has been consumed 
by organic matter to biochemically oxidise over certain time period under strictly defined conditions (Jouanneau et al., 2014). For example, during 7 days at $20^{\circ} \mathrm{C}$.

To evaluate the causes of increase in $\mathrm{BOD}_{7}$ concentrations in rivers' water, a statistical analysis of the data was performed. It was established that the increase in concentrations of organic matter in rivers in water was influenced not only by precipitation, but also by air and water temperature $\left(\mathrm{r}=0.61, \mathrm{~F}_{\text {fact. }}=6.86>\mathrm{F}_{\text {theor. }} .95 \%=2.9, \mathrm{p}=0.00097\right)$. The following equation was obtained:

$$
z=3.693859+0.161416 x_{1}-0.194745 x_{2}+0.283671 x_{3}
$$

here: $z-\mathrm{BOD}_{7}$ concentration in rivers' water $\mathrm{mg} \mathrm{O}_{2} \mathrm{l}^{-1}$;

$x_{1}$-air temperature at the time the sample was taken, ${ }^{\circ} \mathrm{C}$;

$x_{2}$ - water temperature at the time sample was taken, ${ }^{\circ} \mathrm{C}$;

$x_{3}$ - precipitation amount at the time sample was taken, $\mathrm{mm}$.

Using partial correlation, it was found that the precipitation has washed away the sewage from streets, which quickly got into the rivers through dischargers, therefore increasing the concentration of $\mathrm{BOD}_{7}$ in rivers' water $(\mathrm{r}=0.46$, $\left.\mathrm{t}_{\text {fact. }}=2.99>\mathrm{t}_{\text {theor.95\% }}=2.0, \mathrm{p}=0.0052\right)$. This is confirmed by Barałkiewicz et al., (2014) and Mallin et al., (2009), who found that higher concentrations of BOD are present in rainwater in urban areas, as urban areas with impermeable coating increase surface runoff and affect rivers' hydrology and geomorphology (Paul, Meyer, 2008; O'Driscoll et al., 2010).

As already mentioned, the air and water temperature has also affected $\mathrm{BOD}_{7}$ concentrations in the water of the Dotnuvele and Smilga Rivers, respectively $\left(r=0.41, \mathrm{t}_{\text {fact. }}=2.63>\mathrm{t}_{\text {theor. } 95 \%}=2.0, \mathrm{p}=0.013\right)$ and $\left(\mathrm{r}=-0.41, \mathrm{t}_{\text {fact. }}=-2.66>\right.$ $\mathrm{t}_{\text {theor.95\% }}=2.0, \mathrm{p}=0.012$ ). This means that, as the air warms up, the concentrations of organic matter in rivers was increasing due to the influence of the temperature, which provided the conditions for different physical, chemical, biochemical and biological processes in the water (Tilickis, 2005). According to Rudzianskaite (2009), the concentration of BOD begins to increase when the water temperature reaches more than $5{ }^{\circ} \mathrm{C}$.

After analysing the 5-year average concentration fluctuations of $\mathrm{BOD}_{7}$ in the Dotnuvele and Smilga Rivers, it was found that the concentrations were the highest in both of them during quarter II of the year, respectively 3.8 and $4.24 \mathrm{mg} \mathrm{O}_{2} \mathrm{l}^{-1}$ (Fig. 2).

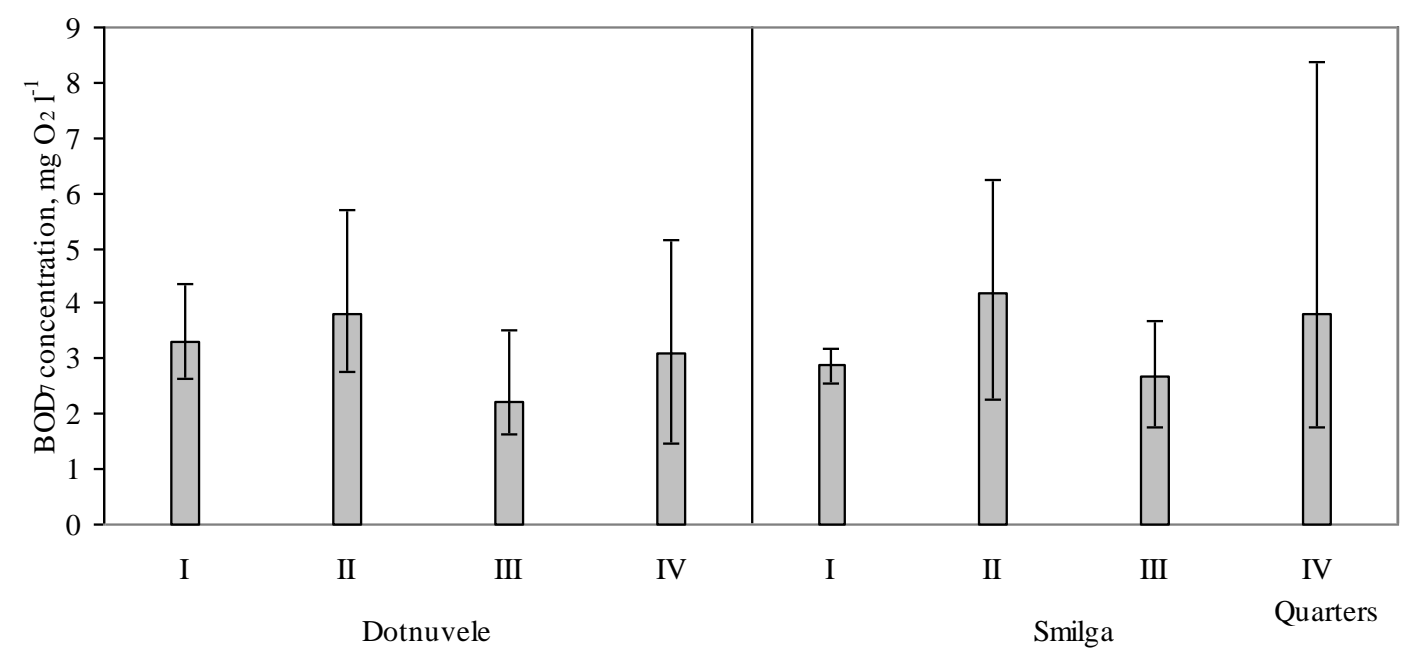

Figure 2. Fluctuations of $\mathrm{BOD}_{7}$ concentrations in rivers' water during the quarters of a year during the research period

The research data showed that concentrations of organic matter in quarter IV were also high: in Dotnuvele - 3.3, in Smilga - $4.32 \mathrm{mg} \mathrm{O}_{2} \mathrm{l}^{-1}$. The deviations of $\mathrm{BOD}_{7}$ concentrations from the average were the highest in the Smilga River, with the highest values found in quarters II and IV, respectively 6.25 and $8.37 \mathrm{mg} \mathrm{O}_{2} \mathrm{l}^{-1}$. The cleanest water in both rivers in terms of organic pollution was determined in quarter III of the researched year, when the Dotnuvele River had an average $\mathrm{BOD}_{7}$ concentration of 2.2, and $2.73 \mathrm{mg} \mathrm{O}_{2} \mathrm{l}^{-1}$ in Smilga.

To ensure the self-cleansing processes in rivers, it is very important to have as much dissolved oxygen as possible. Research showed that the highest concentrations of dissolved oxygen in the Dotnuvele and Smilga Rivers were in quarter I of the year: respectively 11.6 and $12.3 \mathrm{mg} \mathrm{l}^{-1}$. In the other quarters of the year the amount of dissolved oxygen was determined to be slightly lower than in quarter I, respectively: II - 7 and 11\%, III - 35 and 18\%, IV - 13 and 12\% (Table 1).

Table 1. The average dissolved oxygen concentration in rivers' water during the quarters of a year during the research period

\begin{tabular}{|c|c|c|c|c|c|c|c|c|}
\hline \multirow[t]{3}{*}{ Indices } & \multicolumn{8}{|c|}{ Quarters of a Year } \\
\hline & I & II & III & IV & I & II & III & IV \\
\hline & \multicolumn{4}{|c|}{ Dotnuvele } & \multicolumn{4}{|c|}{ Smilga } \\
\hline Average, $\mathrm{mg} \mathrm{l}^{-1}$ & 11.6 & 10.8 & 7.5 & 10.3 & 12.3 & 11.0 & 10.1 & 10.7 \\
\hline Standard deviation, $\mathrm{mg} \mathrm{l}^{-1}$ & 0.79 & 1.49 & 1.09 & 2.5 & 0.96 & 1.51 & 1.58 & 1.4 \\
\hline Confidence 95\% & 0.69 & 1.30 & 0.96 & 2.2 & 0.71 & 1.12 & 1.17 & 1.3 \\
\hline Coefficient of variation, $\%$ & 7 & 14 & 14 & 24 & 8 & 14 & 16 & 13 \\
\hline
\end{tabular}


After comparing the standard deviation values, it can be concluded that the variability of oxygen dissolved in the Dotnuvele and Smilga Rivers was the lowest in quarter I, respectively 0.79 and $0.96 \mathrm{mg}^{-1}$. Not only was the maximum concentration of dissolved oxygen determined in quarter I, but its distribution during the research period was negligible, as the coefficient of variation was calculated in Dotnuvele - 7, and in Smilga - 8\%. Dissolved oxygen concentrations were fluctuating the most in quarter IV: the standard deviation in the Dotnuvele and Smilga Rivers was determined to be 2.5 and $1.4 \mathrm{mg} \mathrm{l}^{-1}$ respectively. The values of coefficients of variation showed that concentrations in the Dotnuvele River in quarter IV of the year were higher than in Smilga, respectively 24 and $13 \%$.

After performing a statistical data analysis of both rivers, it was found that rivers' water temperature and precipitation amount have an impact on the amount of dissolved oxygen in rivers $\left(\mathrm{r}=0.66, \mathrm{~F}_{\text {fact. }}=14.62>\mathrm{F}_{\text {theor. }} .95 \%=3.3\right.$, $\mathrm{p}=0.00002)$.

$$
z=13.02638-0.17749 x_{1}-0.35020 x_{2},
$$

here: $z$ - dissolved oxygen concentration in rivers' water $\mathrm{mg}^{-1}$;

$x_{1}$ - water temperature at the time the sample was taken, ${ }^{\circ} \mathrm{C}$;

$x_{2}$ - precipitation amount at the time the sample was taken, $\mathrm{mm}$.

Partial correlation showed that water temperature has a higher impact on dissolved oxygen amount: the lower the temperature $\left(\mathrm{r}=-0.64, \mathrm{t}_{\text {fact. }}=|-6.7|>\mathrm{t}_{\text {theor. } 95 \%}=2.0, \mathrm{p}=0.00001\right)$ and the lower precipitation amount $\left(\mathrm{r}=-0.45, \mathrm{t}_{\text {fact. }}=\mid-\right.$ $\left.3.5 \mid>t_{\text {theor.95\% }}=2.0, p=0.0042\right)$, the more oxygen is found in the rivers' water.

Due to the dam on the Dotnuvele River, especially during summer, water flow velocity slows down, the water warms up and such conditions hinder the dissolution of oxygen in water, therefore the concentration in quarter III of the year was determined to be the lowest $7.5 \mathrm{mg} \mathrm{l}^{-1}$. Meanwhile, it was 1.3 times higher in the Smilga River.

Based on the average yearly value of each indicator, water bodies are assigned to one of the five ecological status classes. A very good ecological status in a water body is when the concentration of biochemical oxygen consumption $\left(\mathrm{BOD}_{7}\right)$ in water is lower than 2.3, good - when it fluctuates in the range of 2.30 to 3.30, moderate - from 3.31 to 5.0, bad - from 5.01 to 7.0 and very bad - when it is greater than $7.0 \mathrm{mg} \mathrm{O}_{2} \mathrm{l}^{-1}$.

It can be seen in figure 3 that moderate yearly $\mathrm{BOD}_{7}$ concentrations in the Smilga River were higher than in Dotnuvele and were fluctuating between $2.4 \mathrm{mg} \mathrm{O}_{2} \mathrm{l}^{-1}$ in 2014 and $4.2 \mathrm{mg} \mathrm{O}_{2} \mathrm{l}^{-1}$ in 2015 (Fig. 3).

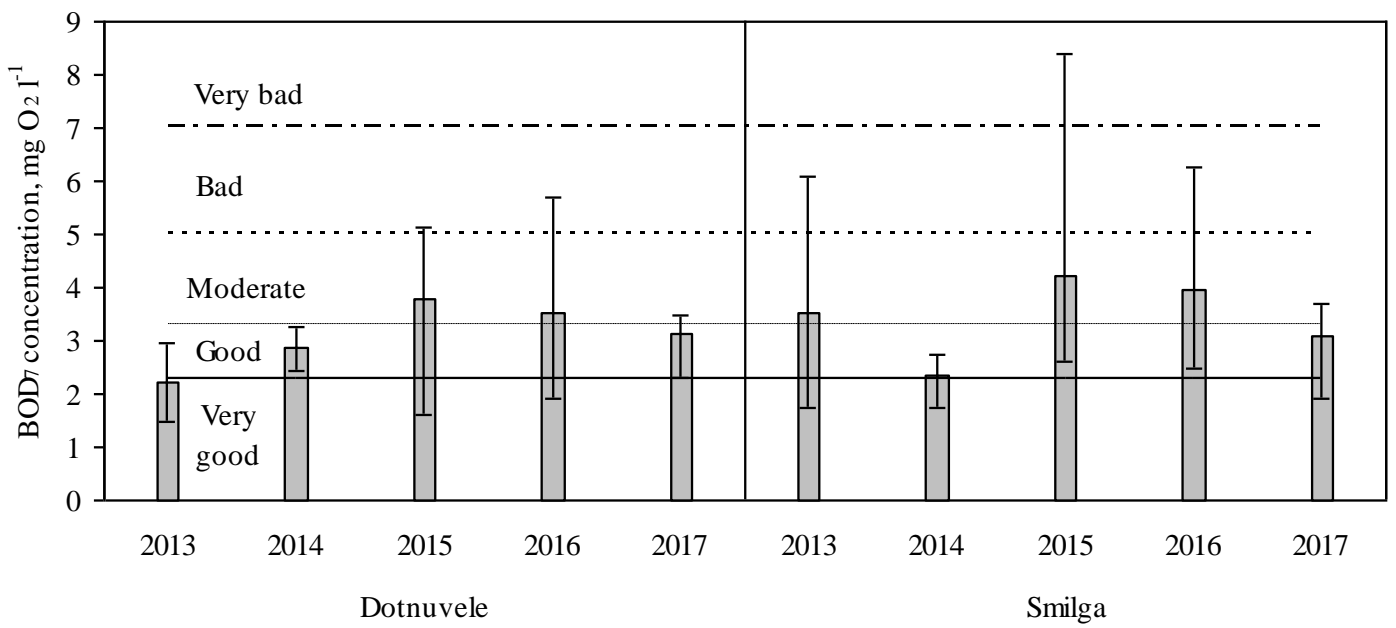

Figure 3. Average yearly $\mathrm{BOD}_{7}$ concentrations in rivers' water during the research period

During the five-year research period, the average $\mathrm{BOD}_{7}$ concentrations in the Smilga River met the moderate ecological status for three years (2013, 2015, and 2016). It was good in 2014 and 2017.

In the Dotnuvele River, the amount of organic pollutants was determined to be slightly lower, but for two years out of five, the river's water has met the moderate ecological status and fluctuated from $3.8 \mathrm{mg} \mathrm{O}_{2} \mathrm{l}^{-1}$ in 2015 to $3.5 \mathrm{mg}$

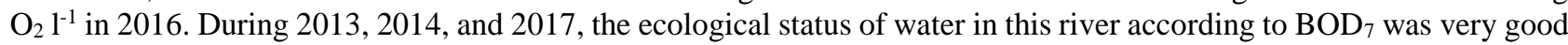
and good.

\section{CONCLUSIONS}

1. It was found that the increase in $\mathrm{BOD}_{7}$ concentrations in rivers' water was influenced not only by precipitation $(\mathrm{r}=$ $0.46)$, but also by air $(\mathrm{r}=0.41)$ and water temperature $(\mathrm{r}=-0.41)$.

2. More dissolved oxygen in the rivers is formed when the temperature of the water is lower $(r=-0.64)$ and when the precipitation is lower $(\mathrm{r}=-0.45)$. 
3. In the case of organic pollution, the Dotnuvele is a slightly cleaner River, but its water for two years (2015 and 2016) was of moderate ecological status. The water of the Smilga River was of moderate ecological status in 2013, 2015 and 2016.

\section{REFERENCES}

1. Barałkiewicz, D., Chudzińska, M., Szpakowska, B., Świerk, D., Gołdyn, R., Dondajewska, R. 2014. Storm water contamination and its effect on the quality of urban surface waters. Environmental Monitoring and Assessment, Vol. 186(10), pp. 6789-6803. https://doi.org/10.1007/s10661-014-3889-0

2. Chen, C-H., Lung, W-S., Li, S-W., Lin, C-F. 2012. Technical challenges with BOD/DO modeling river in Taiwan. Journal of Hydro-environment Research, Vol. 6, pp. 3-8. https://doi.org/10.1016/j.jher.2011.08.001

3. Environmental Protection Agency. 2016. National river monitoring data. Available at http://vanduo.gamta.lt/cms/index?rubricId=6adeeb1d-c902-49ab-81bb-d64b8bccefdd.

4. Gustavsson, L., Engwall, M. 2012. Treatment of sludge containing nitro-aromatic compounds in reed-bed mesocoms - Water, BOD, carbon, nutrient removal. Waste Management, Vol. 32, pp.104-109. https://doi.org/10.1016/j.wasman.2011.08.016

5. . Jouanneau, S., Recoules, L., Durand, M.J., Boukabache, A., Picot, V., Primault, Y., Lakel, A., Sengelin, M., Barillon, B., Thouand G. 2014. Methods for assessing biochemical oxygen demand (BOD): A review. Water Research, Vol. 49(1), pp. 62-82. https://doi.org/10.1016/j.watres.2013.10.066

6. Mallin, M.A., Johnson, V.L., Ensing S.H. 2009. Comparative impacts of stormwater runoff on water quality of an urban, a suburban, and a rural river. Environmental Monitoring and Assessment, Vol. 159(1-4), p.p. 475-91. https://doi.org/10.1007/s10661-008-0644-4

7. Mwinyihija, M. 2010. Ecotoxicological Diagnosis in the Tanning Industry, vol. 17.Springer ScienceBusiness Media, LLC. DOI https://doi.org/10.1007/978-1-4419-6266-9_2

8. Nikanorov, A. M. 1989. Gidrochimija. Gidrometeoizdat, Leningrad. [In Russian].

9. O'Driscoll, M., Clinton, S., Jefferson, A., Manda, A., McMillan, S. 2010. Urbanization Effects on Watershed Hydrology and InStream Processes in the Southern United States. Water, Vol. 2(3), pp. 605-648. https://doi.org/10.3390/w2030605

10. Paul, M.J., Meyer J.L. 2008. Rivers in the Urban Landscape. Marzluff, J.M., Shulenberger, E., Endlicher, W., Alberti, M., Bradley, G., Ryan, C., Simon, U., ZumBrunnen, C. (Eds.), Urban Ecology, pp. 207-231, https://doi.org/10.1007/978-0-387-73412-5

11. Rudzianskaite, A. 2009. The change of organic matter concentration in the upper reaches of Nevėžis. Vandens ūkio inžinerija, No. 35(55), pp. 82-88.

12. Simon, F.X., Penru, Y., Guastalli, A.R., Llorens, J., Baig, S. 2011. Improvement of the analysis of the biochemical oxygen demand (BOD) of Mediterranean seawater by seeding control. Talanta, Vo. 85, pp. 527-532.

13. Surface water bodies' state evaluation methodology. 2010. TAR, No. 21814. [In Lithuanian].

14. Tilickis, B. 2005. Water chemical composition alternation in Lihuanian cathments. Klaipedos universiteto leidykla, Klaipèda. [In Lithuanian].

15. Unified Study Methods of Wastewater and Surface Water Quality. D.1. 1994. Ministry of Environment protection, Vilnius.

16. Wen, Y., Schoups, G., van de Giesen N. 2017. Organic pollution of rivers: Combined threats of urbanization, livestock farming and global climate change. Scientific Reports, Vol. 7, No. 43289. https://doi.org/10.1038/srep43289 